\title{
PENGARUH KOMUNIKASI TERHADAP KINERJA KARYAWAN PADA PT. TASPEN (PERSERO) CABANG PEMATANGSIANTAR
}

\author{
Oleh: \\ Alfiza Rahmadani \\ S1 Manajemen \\ Darwin Lie, Marisi Butarbutar, Efendi
}

\begin{abstract}
Abstraksi
Desain penelitian yang digunakan dalam penelitian ini adalah penelitian kepustakaan dan penelitian lapangan, jenis datanya adalah data kualitatif dan kuantitatif, sumber data primer dan sekunder. Berhubung populasi yang ada kurang dari 100 yaitu 29 orang, maka sampel yang digunakan adalah seluruh populasi (karyawan) yang ada pada PT. Taspen (Persero) Cabang Pematangsiantar. Analisa data yang dilakukan dalam penelitian ini yaitu analisa deskriptif kualitatif dan kuantitatif. Analisa deskriptif kuantitatif terdiri dari regresi linier sederhana, koefisien korelasi, perhitungan koefisien determinasi, dan uji hipotesis (Uji t).

Hasil analisa dari regresi linier sederhana yaitu $\hat{Y}=5,6+0,87 X$, artinya terdapat pengaruh yang positif antara komunikasi terhadap kinerja karyawan. Hasil korelasi yaitu nilai $\mathrm{r}$ sebesar 0,78 yang artinya ada hubungan yang positif dan kuat antara variabel $\mathrm{X}$ yaitu komunikasi dan variabel $\mathrm{Y}$ yaitu kinerja. Analisa koefisien determinasi menunjukkan tinggi rendahnya kinerja dapat dijelaskan oleh komunikasi sebesar 60,84\%, sedangkan $39,16 \%$ dipengaruhi oleh faktor-faktor lain yang tidak dibahas pada penelitian ini. Dari hasil pengolahan dan perhitungan kuesioner, penulis menyimpulkan bahwa komunikasi berpengaruh positif terhadap kinerja karyawan pada PT. Taspen (Persero) Cabang Pematangsiantar. Hal ini dibuktikan secara matematis melalui uji hipotesis, dimana hasil uji $t_{\text {hit }}(6,47)>t_{\text {tab }}(2,052)$. Untuk itu, perlu adanya peningkatan hubungan komunikasi pada PT. Taspen (Persero) Cabang Pematangsiantar untuk menghasilkan kinerja karyawan yang tinggi.
\end{abstract}

Kata Kunci: Komunikasi dan Kinerja Karyawan

\section{Abstraction}

Desain research used in research is library research and field research, its data type is data qualitative and quantitative, source of data is primary and secunder. Linking existing population less than 100 that is 29 people, hence sampel used is population (officer) of exist in PT. Taspen (Persero) Branch the Pematangsiantar. Analyse the data of performed within this research that is descriptive analysis qualitative and quantitative. The quantitative Descriptive analysis consisted of linear regresi modestly, correlation coefficient, calculation of coefficient determinasi, and test the hypothesis (Test $t$ ).

Result of analysis from linear regresi modestly that is $\hat{Y}=5,6+0,87 X$, its meaning there are influence which are positive between communications to employees performance. Result of correlation that is assess the $r$ equal to 0,78 which its meaning there is relation which are positive and strong between variable $X$ that is communications and variable $Y$ that is performance. Analyse the coefficient determinasi show high lower the explainable performance by communications equal to 60,84\%, while 39,16\% influenced by other factors which is not studied at this research. From result of processing and calculation questionnaires, writer conclude that communications have an effect on positive to employees performance at PT. Taspen (Persero) Branch the Pematangsiantar. This Matter is proved by mathematically through hypothesis test, where result test the $t_{\text {hit }}$ $(6,47)>t_{t a b}$ (2,052). For that, need the existence of the communications relation at PT. Taspen (Persero) Branch the Pematangsiantar to yield the high employees performance.

Keywords: Communications and Officer Performance

\section{A. PENDAhULUAN}

\section{Latar Belakang Masalah}

Saat ini organisasi banyak mengalami perubahan dan perkembangan yang sangat kompleks dan cepat sekali dalam pencapaian tujuan perusahaan. Untuk itu, organisasi dituntut untuk menghasilkan kinerja karyawan yang tinggi demi kemajuan perusahaan. Sebagai aset utama yang terpenting dalam perusahaan sumber daya manusia memiliki peran utama dalam menentukan keberhasilan suatu perusahaan. Karena sumber daya manusia memiliki berbagai fungsi manajemen yang dapat digunakan untuk pencapaian tujuan perusahaan.

PT. Taspen Taspen (Persero) Cabang Pematangsiantar sebagai perusahaan yang bergerak di bidang Program Asuransi Sosial Pegawai Negeri Sipil memandang kinerja sebagai hal yang utama dalam pencapaian tujuan. Untuk mencapai hal ini maka para karyawan yang satu dengan yang lainnya harus bekerja sama dalam meningkatkan kinerja mereka. Tetapi pada kenyataannya fenomena yang sering terjadi pada PT. Taspen (Persero) Cabang Pematangsiantar menunjukkan kinerja yang masih belum optimal. Hal ini dapat dilihat dari masih 
seringnya para karyawan yang hadir tidak tepat waktu, kuantitas dan kualitas hasil pekerjaan yang belum optimal, ketepatan waktu dalam melakukan pekerjaan dan sikap kerja sama karyawan sebagai indikator kinerja.

Salah satu fakor yang mempengaruhi kinerja adalah komunikasi. Berdasarkan pengamatan penulis, komunikasi yang terjalin pada PT. Taspen (Persero) Cabang Pematangsiantar terdiri komunikator, pesan, komunikan, saluran/media dan efek. Namun fenomena yang terjadi pada PT. Taspen (Persero) Cabang Pematangsiantar menunjukan hubungan komunikasi yang belum optimal, hal ini disebabkan karena masih sering terjadi salah paham antara karyawan dengan karyawan maupun antara karyawan dengan pimpinan.

Hal ini terjadi karena penyampaian pesan yang tidak jelas dan respon berbeda yang diperlihatkan oleh penerima pesan. Dalam hal ini masing-masing individu dituntut harus mampu berkomunikasi dengan baik agar tidak terjadi salah paham dalam menyampaikan atau menerima pesan, sehingga diharapkan dengan jalinan komunikasi yang baik mampu meningkatkan kinerja karyawan pada PT. Taspen (Persero) cabang Pematangsiantar.

\section{Rumusan Masalah}

a. Bagaimana kondisi komunikasi dan kinerja karyawan pada PT. Taspen (Persero) Cabang Pematangsiantar?

b. Seberapa besar pengaruh komunikasi terhadap kinerja karyawan pada PT. Taspen (Persero) Cabang Pematangsiantar?

\section{Tujuan Penelitian}

a. Untuk mengetahui kondisi komunikasi dan kinerja karyawan pada PT. Taspen (Persero) Cabang Pematangsiantar.

b. Untuk mengetahui besarnya pengaruh komunikasi terhadap kinerja karyawan pada PT. Taspen (Persero) Cabang Pematangsiantar.

\section{Metode Penelitian}

Desain penelitian merupakan suatu cara yang sistematis dan objektif dengan maksud untuk memperoleh data atau mengumpulkan keterangan untuk diteliti. Adapun Desain penelitian yang digunakan dalam penulisan skripsi ini adalah Penelitian Kepustakaan (Library Research) dan Penelitian Lapangan (Field Research).

Teknik pengumpulan data yang dilakukan penulis dalam penelitian ini adalah berupa Kuesioner, Wawancara dan Dokumentasi. Adapun jenis data yang digunakan dalam penelitian ini adalah jenis data kualitatif dan data kuantitatif. Hasil data yang diperoleh dari lapangan akan dianalisis secara deskriptif baik bersifat kualitatif dan kuantitatif.

\section{B. LANDASAN TEORI}

Manajemen merupakan proses pendayagunaan bahan baku dan sumber daya manusia untuk mencapai tujuan yang ditetapkan. Menurut Daft (2007:6), manajemen adalah pencapaian tujuan organisasi dengan cara yang efektif melalui perencanaan, pengorganisasian, pengarahan, dan pengendalian sumber daya organisasi. Melalui manajemen dilakukan proses pengintegrasian berbagai sumber daya dan tugas untuk mencapai berbagai tujuan organisasi.

Menurut Mondy (2008:4), manajemen sumber daya manusia adalah pemanfaatan sejumlah individu untuk mencapai tujuan-tujuan organisasi. Sedangkan Dessler (2006:5), mengemukakan bahwa manajemen sumber daya manusia adalah proses memperoleh, melatih, menilai, dan memberikan kompensasi kepada karyawan, memperhatikan hubungan kerja mereka, kesehatan, keamanan, dan masalah keadilan. Berdasarkan pendapat para ahli di atas, dapat disimpulkan bahwa manajemen sumber daya manusia adalah suatu kebijakan yang dilakukan oleh tiap-tiap organisasi atau perusahaan dalam memberdayakan orang-orang yang ada di dalamnya untuk mencapai tujuan organisasi.

Sumber daya manusia dalam sebuah organisasi, walaupun telah direkrut melalui seleksi yang baik, namun dalam melaksanakan tugasnya masih selalu menghadapi persoalan yang tidak dapat diselesaikan sendiri. Fungsi sumber daya manusia merupakan basis dari pelaksanaan proses manajemen sumber daya manusia yang efektif dan efisien dalam mencapai tujuan organisasi atau perusahaan. Fungsi manajemen sumber daya manusia menurut Mondy (2008:4), pada dasarnya ada lima jenis yaitu:

1. Penyediaan staf, merupakan proses yang menjamin suatu organisasi untuk selalu memiliki jumlah karyawan yang tepat dengan keahliankeahlian yang memadai dalam pekerjaanpekerjaan tepat pada waktunya untuk mencapai tujuan organisasi.

2. Pengembangan sumber daya manusia. Fungsi manajemen sumber daya manusia utama yang tidak hanya terdiri atas pelatihan dan pengembangan namun juga aktivitas-aktivitas perencanaan dan pengembangan karier individu, organisasi, serta manajemen dan penilaian kinerja.

3. Kompensasi. Suatu sistem kompensasi yang terencana matang memberi para karyawan imbalan-imbalan yang layak dan andil atas kontribusi mereka dalam mencapai tujuan-tujuan organisasi.

4. Kesehatan dan keselamatan. Keselamatan adalah perlindungan bagi para karyawan yang disebabkan kecelakaan-kecelakaan yang terkait dengan pekerjaan. Kesehatan adalah bebasnya para karyawan dari sakit fisik atau emosi.

5. Hubungan kekaryawanan dan perburuhan. Hubungan karyawan dengan pihak perusahaan haruslah dijaga dengan baik, agar karyawan lebih termotivasi untuk mencapai tujuan perusahaan yang telah ditetapkan.

Setiap individu dalam suatu organisasi dalam kehidupan sehari-harinya tidak dapat dilepaskan 
dengan dunia komunikasi. Menurut Dewi (2007:9), Komunikasi adalah suatu pertukaran, proses simbolik yang menghendaki orang-orang agar mengatur lingkungannya dengan membangun hubungan antar sesama manusia melalui pertukaran informasi untuk mengkuatkan sikap dan tingkah laku orang lain, serta berusaha mengubah sikap dan tingkah laku itu. Sedangkan Himstreet dan Baty dalam Purwanto (2006:3), menyatakan bahwa komunikasi adalah suatu proses pertukaran informasi antar individu melalui suatu sistem yang biasa (lazim) baik dengan simbol-simbol, sinyalsinyal, maupun perilaku atau tindakan. Dari uraian diatas dapat disimpulkan bahwa komunikasi pada dasarnya adalah sebuah proses penyampaian dan pertukaran informasi. Komunikasi merupakan kegiatan pengiriman dan penerimaan pesan.

Menurut Bovve dan Thill dalam Purwanto (2006:11), proses komunikasi terdiri dari enam tahapan, yaitu:

1. Pengirim mempunyai suatu ide atau gagasan.

2. Pengirim mempunyai ide menjadi suatu pesan.

3. Pengirim menyampaikan pesan.

4. Penerima menerima pesan.

5. Penerima menafsirkan pesan.

6. Penerima memberi tanggapan dan mengirim umpan balik kepada pengirimnya.

Kinerja adalah bagian dari produktivitas kerja, produktivitas berasal dari kata "produktif" artinya sesuatu yang mendukung potensi untuk digali, sehingga produktivitas dapat dikatakan suatu proses kegiatan yang terstruktur guna menggali potensi yang ada dalam sebuah komoditi atau objek. Menurut Wibowo (2007:123) kinerja berasal dari pengertian performance, kinerja merupakan hasil pekerjaan yang mempunyai hubungan kuat dengan tujuan strategis organisasi, kepuasan konsumen, dan memberikan kontribusi pada ekonomi. Sedangkan, Mathis dan John (2006:378), mengemukakan bahwa kinerja (performance) adalah apa yang dilakukan atau tidak dilakukan oleh karyawan. Dari pendapat di atas dapat diambil kesimpulan bahwa kinerja karyawan merupakan suatu kemajuan atau pencapaian hasil kerja dengan kriteria tertentu yang dilakukannya berdasarkan potensi yang dimilikinya dengan penilaian dari orang tertentu.

Indikator kinerja adalah ukuran kuantitatif atau kualitatif yang menggambarkan tingkat pencapaian suatu sasaran atau tujuan yang telah diharapkan. Indikator kinerja harus merupakan sesuatu yang dapat dihitung dan diukur serta digunakan sebagai dasar untuk menilai atau melihat tingkat kinerja. Menurut Miner dalam Sutrisno (2010:172), terdapat empat aspek dari kinerja, yaitu:

1. Kualitas yang dihasilkan, menerangkan tentang jumlah kesalahan, waktu, dan ketepatan dalam melakukan tugas.

2. Kuantitas yang dihasilkan, berkenaan dengan berapa jumlah produk atau jasa yang dapat dihasilkan.

3. Waktu kerja, menerangkan akan berapa jumlah absen, keterlambatan, serta masa kerja yang telah dijalani individu pegawai tersebut.
4. Kerjasama, menerangkan akan bagaimana individu membantu atau menghambat usaha dari teman sekerjanya.

Menurut Luthans (2006:384), jika ditangani secara tepat, mengkomunikasikan pemikiran kerja, hubungan ideologi kerja dengan tujuan organisasi dan informasi, mengenai kinerja kepada karyawan akan sangat menguntungkan organisasi. Hal ini berarti komunikasi sangat mempengaruhi kinerja karyawan dalam pelaksanaan tugas.

Menurut Dewi dalam Halim (2012:52), kinerja yang tinggi dapat didukung oleh komunikasi yang efektif, bagaimana karyawan berinteraksi, menyampaikan informasi, bertukar gagasan, baik antara atasan ke bawahan maupun sebaliknya, antara karyawan dengan karyawan, maupun karyawan pada satu bagian ke bagian lainnya. Proses koumunikasi adalah pemindahan pengertian dalam bentuk gagasan atau informasi dari satu orang ke orang lain lebih dari sekedar kata-kata yang digunakan dalam percakapan tetapi juga ekspresi wajah, intonasi, vokal dan sebagainya. Proses komunikasi yang begitu dinamik dapat menimbulkan berbagai masalah yang mempengaruhi pencapaian sebuah organisasi.

Dari uraian diatas, penulis dapat menyimpulkan bahwa pemimpin dalam suatu perusahaan harus mampu berkomunikasi dengan baik dengan para bawahannya, dengan tujuan untuk menjalin hubungan yang baik dengan bawahannya, meningkatkan kerja sama, dan menggerakan para karyawan agar semakin efektif dalam bekerja. Akan tetapi semua hal tersebut akan menjadi hal yang siasia apabila tidak ada dorongan minat dari diri para karyawan untuk lebih memperhatikan pekerjaannya. Berdasarkan uraian diatas sangat diharapkan agar komunikasi terjalin dengan baik antara pimpinan dengan bawahan atau sebaliknya dan antara sesama karyawan untuk meningkatkan kinerja karyawan itu sendiri.

\section{PEMBAHASAN}

\section{Analisa \\ a. Deskriptif Kualitatif}

Analisis deskriptif dimaksudkan untuk mendapatkan gambaran atau deskripsi mengenai tanggapan dari karyawan mengenai Pengaruh Komunikasi Terhadap Kinerja Karyawan pada PT. Taspen (Persero) Cabang Pematangsiantar. Sesudah pengujian data, maka langkah selanjutnya peneliti melakukan pengkajian analisa kualitatif sebagai gambaran fenomena dari variabel penelitian pada saat sekarang ini.

Adapun penetapan kriteria nilai rata-rata jawaban dari responden tersebut dimasukkan ke dalam kelas-kelas interval dimana penentuan intervalnya memakai rumus sebagai berikut:

Interval Kelas $=\underline{\text { Nilai Tertinggi-Nilai Terendah }}$

Interval Kelas $=\frac{5-1}{5}$

Interval Kelas $=\frac{4}{5}=0,8$ 
Dari rumus diatas diperoleh interval kelas = 0,8 , sehingga berlaku ketentuan kategori dengan hasil sebagai berikut:

Tabel 1

Nilai Interval dan Kategori Jawaban Responden

\begin{tabular}{|c|c|}
\hline Nilai Interval & Kategori \\
\hline $1,00-1,80$ & $\begin{array}{c}\text { Sangat Tidak } \\
\text { Baik/Sangat Rendah } \\
\text { Tidak Baik/Rendah }\end{array}$ \\
\hline $1,81-2,60$ & $\begin{array}{c}\text { Kurang Baik/Cukup } \\
\text { Tinggi }\end{array}$ \\
\hline $2,61-3,40$ & Baik/Tinggi \\
\hline $3,41-4,20$ & $\begin{array}{c}\text { Sangat Baik/Sangat } \\
\text { Tinggi }\end{array}$ \\
\hline $4,21-5,00$ & \\
\hline
\end{tabular}

Sumber: Hasil Pengolahan Data

\section{1) Komunikasi Karyawan pada PT. Taspen (Persero) Cabang Pematangsiantar}

Salah satu faktor yang mempengaruhi kinerja adalah komunikasi. Komunikasi sangat berpengaruh dalam pelaksanaan pekerjaan para kinerja. Karena segala sesuatu tidak mungkin berjalan dengan lancar apabila komunikasi tidak terjalin dengan baik. Komunikasi dikatakan efektif apabila penyampaian maksud dan tujuan dari komunikasi itu dipahami oleh penerima pesan. Komunikasi yang terjadi pada PT. Taspen (Persero) cabang Pematangsiantar yaitu komunikasi secara internal dan eksternal.

Komunikasi internal yaitu hubungan komunikasi yang terjadi antara pimpinan dan bawahan. Komunikasi seperti ini terjadi ketika pimpinan PT. Taspen (Persero) cabang Pematangsiantar memberikan instruksi kepada karyawannya, baik ketika melakukan pekerjaan sehari-hari atau saat rapat bulanan. Hal lain yang sering terjadi yaitu ketika para karyawan PT. Taspen (Persero) cabang Pematangsiantar memberikan laporan hasil kerja. Komunikasi inilah yang paling sering digunakan dalam melakukan kegiatan kerja sehari-hari. PT. Taspen (Persero) cabang Pematangsiantar juga menjalin hubungan komunikasi secara eksternal yaitu dengan nasabah. Melayani nasabah adalah hal yang paling diutamakan pada perusahaan ini. Karena semua program kerja para karyawan berasal dari data-data yang berasal dari para nasabah tersebut. Oleh karena itu, kepuasan nasabah harus dipertahankan dengan meningkatkan kualitas jasa pelayanan.

Hubungan komunikasi yang terjalin pada PT. Taspen (Persero) cabang Pematangsiantar meliputi tiga tipe komunikasi yaitu:

a) Komunikasi Dengan Diri Sendiri

Komunikasi dengan diri sendiri sering terjadi ketika pimpinan PT. Taspen (Persero) Cabang Pematangsiantar berkomunikasi dengan dirinya sendiri dalam hal mengambil keputusan, karena setiap kebijakan yang dikeluarkannya sangat berpengaruh dalam organisasi tersebut.

b) Komunikasi Antarpribadi/Antarpersonal

Pimpinan pada PT. Taspen (Persero) Cabang Pematangsiantar menggunakan jenis komunikasi ini untuk lebih dekat dan mengakrabkan diri pada karyawan. Dengan situasi ini maka akan tercipta suasana yang bersahabat pada organisasi. Dalam komunikasi ini karyawan mendapat kesempatan untuk saling berbagi cerita pada pimpinan. Karyawan mungkin bisa menceritakan keluhan dalam pekerjaannya atau bahkan berbagi cerita masalah pribadi. Karena dalam suatu organisasi apabila karyawan sedang dalam keadaan menghadapi masalah, maka pekerjaan tidak berjalan secara efektif dan efisien sehingga akan mengurangi produktivitas pekerjaan.

c) Komunikasi Kelompok Kecil

Komunikasi ini melibatkan beberapa orang. Hubungan komunikasi kelompok pada PT. Taspen (Persero) Cabang Pematangsiantar dapat dicontohkan dari masing-masing bidang. Seperti contoh pada bagian administrasi keuangan. Kasir mencetak voucher dan kemudian meminta tanda tangan kepada kepala bidang administrasi keuangan dan kemudian berlanjut pada tanda tangan kepala bidang kas. Komunikasi semacam inilah yang dikatakan komunikasi kelompok kecil. Komunikasi ini dilakukan untuk menciptakan koordinasi yang baik antara atasan dan bawahan ataupun sebaliknya sehingga dapat menyusun suatu laporan yang tepat dan tidak menimbulkan kesalahpahaman di kemudian hari.

Dari hasil kuesioner dapat dilihat bahwa total jawaban responden berada pada nilai rata-rata 3,78 dan berada pada kategori baik. Hal ini disebabkan karena komunikator yang bersumber dari pimpinan mengetahui kebutuhan karyawan dan bersikap ramah. Pesan yang disampaikan pimpinan dan karyawan dapat disampaikan dengan baik. Komunikan menerima instruksi pekerjaan yang jelas. Saluran komunikasi terjalin dengan baik dan menimbulkan efek terhadap hubungan komunikasi di dalam suatu perusahaan.

Dalam hal pimpinan bersikap ramah terhadap karyawannya memiliki nilai rata-rata 4,10 berada pada kriteria baik. Adapun pada kategori pimpinan dapat memahami kebutuhan karyawannya berada pada nilai rata-rata 3,59 yang dinilai baik namun lebih rendah nilainya dari sebelumnya. Hal ini disebabkan oleh cara pandang dan penyampaian yang berbeda antara pimpinan pada karyawan ataupun sebaliknya.

Selanjutnya pada indikator pesan, dalam hal pimpinan menyampaikan pesan dengan jelas kepada karyawan berada pada nilai rata-rata 3,72 dan dinilai baik. Sedangkan dalam hal karyawan dapat memberitahu pimpinan ketika ada sesuatu yang tidak beres berada pada nilai rata-rata 3,86 yang dinilai baik dan nilainya lebih tinggi dari nilai sebelumnya. Hal ini disebabkan karena karyawan tidak menginginkan terjadi kesalahan dalam pekerjaan mereka.

Sedangkan pada indikator komunikan dengan pertanyaan pada karyawan dapat mengerjakan tugas sesuai dengan perintah pimpinan berada pada ratarata 3,86 dan nilainya baik. Pada kuesioner karyawan menerima penjelasan instruksi pekerjaan dengan jelas dari pimpinan berada pada rata-rata 3,93 dan berada pada rata-rata lebih tinggi dari yang 
sebelumnya. Hal ini disebabkan oleh perbedaan kemampuan yang dimiliki karyawan dalam menerima penjelasan yang disampaikan.

Sedangkan pada indikator saluran, pimpinan memberikan tugas melalui media elektronik dengan jelas berada pada rata-rata 3,45 dan dinilai baik. Pada pertanyaan karyawan dapat menyampaikan opini pada saat rapat bulanan berada pada rata-rata 3,59 dan dinilai baik. Rata-rata mengalami perbedaan, ini disebabkan oleh hak suara karyawan dan pentingnya suara para karyawan saat rapat bulanan.

Dalam hal indikator efek, untuk pertanyaan hubungan karyawan dengan pimpinan terjalin dengan baik berada pada rata-rata 3,86 dan nilainya baik. Untuk pertanyaan hubungan karyawan dengan rekan kerja terjalin dengan baik berada pada ratarata 3,93 dan nilainya baik. Hal ini disebabkan oleh baiknya jalinan komunikasi antara pimpinan dan kayawan atau sebaliknya serta antara sesama karyawan.

\section{2) Kinerja Karyawan pada PT Taspen (Persero) Cabang Pematangsiantar}

Kinerja adalah hasil pekerjaan yang dicapai dari suatu pekerjaan yang dilakukan. Untuk mengetahui kinerja seorang karyawan diperlukan penilaian kinerja. Adapun faktor-faktor yang mempengaruhi kinerja karyawan pada PT. Taspen (Persero) Cabang Pematangsiantar, yaitu:

a) Faktor Individu

Secara psikologis, karyawan pada PT. Taspen (Persero) Cabang Pematangsiantar memiliki integritas yang tinggi. Dengan adanya integritas yang tinggi maka karyawan pada PT. Taspen (Persero) Cabang Pematangsiantar memiliki konsentrasi diri yang baik. Konsentrasi yang baik ini merupakan modal utama karyawan PT. Taspen (Persero) Cabang Pematangsiantar untuk mampu mengelola dan mendayagunakan potensi dirinya secara optimal dalam melaksanakan kegiatan atau aktivitas kerja sehari-hari dalam mencapai tujuan perusahaan.

b) Faktor Lingkungan Organisasi

Faktor lingkungan organisasi ini sangat menunjang kinerja karyawan pada PT. Taspen (Persero) Cabang Pematangsiantar. Faktor lingkungan organisasi yang dimaksud antara lain jabatan yang jelas, otoritas yang memadai, target kerja yang menantang, komunikasi yang efektif, hubungan kerja yang harmonis, iklim kerja yang respek dan dinamis, peluang karir dan fasilitas kerja yang relatif memadai. Faktor lingkungan organisasi seperti inilah yang menjadi sasaran atau target para karyawan pada PT. Taspen (Persero) Cabang Pematangsiantar.

Dalam menilai kerja karyawan, PT. Taspen (Persero) Cabang Pematangsiantar melaksanakan penilaian untuk bisa menentukan karyawan mana yang mampu dalam menyelesaikan pekerjaan dengan baik maupun sebaliknya. Selain bertujuan untuk meningkatkan kinerja karyawan, penilaian ini juga membantu pihak manajemen dalam mengembangkan potensi karyawan dengan melakukan promosi atau menentukan dalam pemutusan hubungan kerja guna mencapai tujuan yang telah ditetapkan.

Dari hasil kuesioner dapat dilihat bahwa sebagian total jawaban responden berada pada ratarata 3,85 dan berada pada kriteria tinggi, hal ini dinilai dari segi kualitas kerja, kuantitas kerja, ketepatan waktu, kehadiran dan kemampuan bekerjasama. Meskipun sudah berada pada rata-rata dan kriteria tinggi, namun dalam hal ini pimpinan diharapkan dapat lebih memperhatikan hal-hal yang menjadi indikator penilaian kinerja dan hal-hal yang dapat meningkatkan kinerja karyawan pada PT. Taspen (Persero) Cabang Pematangsiantar agar lebih maksimal.

Pada indikator kuantitas, tingkat pencapaian target kerja karyawan berada pada rata-rata 3,86 dan dinilai tinggi. Hal ini selaras dengan tingkat penyelesaian pekerjaan utama karyawan yang berada pada rata-rata 3, 86 dan dinilai tinggi. Rata-rata yang diperoleh sama besar, hal ini disebabkan oleh adanya semangat karyawan yang sama besar dalam menyelesaikan pekerjaan mereka. Dari indikator kualitas, perbandingan mutu pekerjaan karyawan berada pada rata-rata 3,62 dan dinilai tinggi. Kemudian dalam hal standar kualitas karyawan dibandingkan dengan karyawan lain berada pada rata-rata 3,69 dan dinilai tinggi. Nilai rata-rata ini lebih tinggi dari sebelumnya, hal ini disebabkan oleh hasil pekerjaan yang dihasilkan karyawan memuaskan sesuai dengan prosedur yang ada.

Sedangkan pada indikator ketepatan waktu, efisensi waktu antara karyawan secara rata-rata berada pada rata-rata 3,86 dan dinilai tinggi. Ketepatan waktu dalam melaksanakan pekerjaan berada pada rata-rata 3,79 dan dinilai tinggi. Hal ini disebabkan oleh sikap karyawan yang tidak menunda pekerjaan mereka. Selanjutnya pada indikator kehadiran, tingkat kehadiran karyawan dengan tepat waktu dikantor berada pada rata-rata 3,93 dan dinilai tinggi. Pemberian sanksi apabila terlambat hadir di kantor berada pada rata-rata 4,31 dan dinilai sangat tinggi. Ini sangat berbeda jauh dengan penilaian yang lain, karena berada pada kriteria sangat tinggi. Hal ini disebabkan oleh setujunya para karyawan terhadap sikap disiplin dan pemberian sanksi apabila melanggar aturan yang ditetapkan pada perusahaan.

Kemudian pada indikator kemampuan kerjasama, kemampuan karyawan untuk membangun kerjasama dengan teman kerja berada pada rata-rata 3,90 dan dinilai tinggi. Kemampuan untuk bekerjasama dengan pimpinan berada pada rata-rata 3,66 dan dinilai tinggi. Hal ini disebabkan oleh perbedaan kepribadian dan budaya karyawan yang berpengaruh terhadap kerjasama antara karyawan dan kepada pimpinan dalam perusahaan.

\section{b. Deskriptif Kuantitatif}

\section{1) Analisa Regresi Linear Sederhana}

Penilaian ini memliki tujuan untuk menganalisa pengaruh komunikasi terhadap kinerja 
karyawan. Analisa data dalam penelitian ini menggunakan analisis regresi sederhana. Analisa regresi linier sederhana digunakan untuk mengetahui pengaruh variabel bebas $(\mathrm{X})$ dan variabel terikat $(\mathrm{Y})$, dimana $\mathrm{X}$ adalah komunikasi dan $\mathrm{Y}$ adalah kinerja karyawan.

Analisa dilakukan dengan melakukan tabulasi jawaban responden pada kuesioner yang telah dijalankan. Untuk melihat pengaruh variabel dengan persamaan regresi tersebut, maka dilakukan perhitungan secara manual untuk memperoleh nilai a dan nilai $b$, dengan notasi sebagai berikut:

$$
\hat{\mathbf{Y}}=\mathbf{a}+\mathbf{b X}
$$

Untuk nilai $\mathrm{b}$ :

$$
\begin{aligned}
& \mathrm{b}=\frac{\mathrm{n}\left(\sum \mathrm{XY}\right)-\left(\sum \mathrm{X}\right)\left(\sum \mathrm{Y}\right)}{\mathrm{n}\left(\sum \mathrm{X}^{2}\right)-\left(\sum \mathrm{X}\right)^{2}} \\
& \mathrm{~b}=\frac{29(42.749)-(1.095)(1.116)}{29(42.045)-(1.095)^{2}} \\
& \mathrm{~b}=\frac{1.239 .721-1.222 .020}{1.219 .305-1.119 .025} \\
& \mathrm{~b}=\frac{17.701}{20.280} \\
& \mathbf{b}=\mathbf{0 . 8 7}
\end{aligned}
$$

sedangkan untuk nilai a:

$$
\begin{aligned}
& \mathrm{a}=\left(\sum \mathrm{Y}-\mathrm{b} \sum \mathrm{X}\right) / \mathrm{n} \\
& \mathrm{a}=(1.116-0,87(1.095)) / 29 \\
& \mathrm{a}=1.116-952,65 / 29 \\
& \mathrm{a}=163,35 / 29 \\
& \mathbf{a}=\mathbf{5 , 6}
\end{aligned}
$$

Berdasarkan hasil pengolahan data didapat persamaan regresi linier sederhana sebagai berikut: $\hat{\mathbf{Y}}=\mathbf{5 , 6}+\mathbf{0 , 8 7 X}$ artinya, terdapat pengaruh yang positif antara variabel bebas (Komunikasi) terhadap variabel terikat (Kinerja) pada PT. Taspen (Persero) cabang Pematangsiantar. Dimana semakin baik atau efektif komunikasi yang dilakukan maka semakin tinggi kinerja karyawan

\section{2) Analisa Korelasi dan Koefisien Determinasi}

Analisis distribusi frekuensi jawaban responden menurut skor dari variabel $\mathrm{X}$ dan $\mathrm{Y}$ dimaksud sebagaimana yang telah dilakukan hanya bermanfaat untuk memberikan informasi pendahuluan mengenai pola distribusi jawaban responden menurut skor. Selanjutnya dilakukan perhitungan korelasi berupa derajat atau kedalaman hubungan fungsional yang menjelaskan hubungna antar perubah, dinyatakan dengan yang dinamakan koefisien yang sering disimbolkan dengan $r$. Nilai $r$ dapat dihitung sabagai berikut:

$$
\begin{aligned}
& r=\frac{\mathrm{n} \Sigma \mathrm{XY}-\Sigma \mathrm{XX} V}{\sqrt{n \sum X^{2}-\left(\sum X\right)^{2}} \sqrt{\mathrm{n \Sigma \textrm {Y } ^ { 2 } - ( \Sigma \mathrm { Y } ) ^ { 2 }}}} \\
& \mathrm{r}=\frac{29(42.749)-(1.095)(1.116)}{\sqrt{\sqrt{29(42.045)-(1.095)^{2}} \sqrt{29(43.822)-(1.116)^{2}}}} \\
& \mathrm{r}=\frac{1.239 .721-1.222 .020}{\sqrt{1.219 .305-1.199 .025} \sqrt{1.270 .838-1.245 .456}}
\end{aligned}
$$

$$
\begin{aligned}
& r=\frac{17.701}{\sqrt{20.280} \sqrt{25.382}} \\
& r=\frac{17.701}{(142,40)(159,31)} \\
& r=\frac{17.701}{22.685,744} \\
& \mathbf{r}=\mathbf{0 , 7 8}
\end{aligned}
$$

Dari hasil perhitungan diatas, terdapat hubungan yang kuat antara variabel $X$ yaitu Komunikasi terhadap variabel $\mathrm{Y}$ yaitu Kinerja. Untuk mengukur seberapa besar variabel bebas menjelaskan variabel terikat maka digunakan koefisien determinasi (KD). Nilai KD dapat diperoleh dari:

$\mathrm{KD}=(\mathrm{r})^{2} \times 100 \%$

$\mathrm{KD}=(0,78)^{2} \times 100 \%$

$\mathrm{KD}=0,6084 \times 100 \%$

$\mathrm{KD}=\mathbf{6 0 , 8 4 \%}$

Analisa koefisien determinasi menunjukkan tinggi rendahnya kinerja dapat dijelaskan oleh komunikasi sebesar 60,84\%, sedangkan 39,16\% dipengaruhi oleh faktor-faktor lain yang tidak dibahas pada penelitian ini.

\section{3) Uji Hipotesis (Uji t)}

Uji $\mathrm{t}$ digunakan untuk menguji pengaruh variabel bebas terhadap variabel terikat secara parsial atau individual. Untuk menguji hasil perhitungan regresi dapat dilakukan pembuktian hipotesa untuk mengetahui apakah variabel bebas mempunyai pengaruh atau tidak terhadap variabel terikat secara parsial.

$$
\begin{aligned}
t_{\text {hit }} & =\frac{\mathrm{r} \sqrt{\mathrm{n}-\overline{2}}}{\sqrt{1-\mathrm{r}^{2}}} \\
t_{\text {hit }} & =\frac{0,78 \sqrt{29}-\overline{2}}{\sqrt{1-0,78^{2}}} \\
t_{\text {hit }} & =\frac{0,78 \sqrt{27}}{\sqrt{1-0,6084}} \\
t_{\text {hit }} & =\frac{0,78(5,19)}{\sqrt{0,3916}} \\
t_{\text {hit }} & =\frac{4,0482}{0,625} \\
\mathbf{t}_{\text {hit }} & =\mathbf{6 , 4 7}
\end{aligned}
$$$$
\text { Maka dapat dihitung } t_{\text {hit }} \text { sebagai berikut: }
$$

Dari hasil pengujian $t_{\text {hit }}$ sebesar 6,47 sedangkan $t_{\text {tab }}$ pada tingkat kepercayaan $95 \%$ adalah sebesar 2,052. Oleh karena $t_{\text {hit }}>t_{\text {tab }}$, maka Ho ditolak dan Ha diterima, artinya komunikasi berpengaruh positif terhadap kinerja karyawan pada PT Taspen (Persero) cabang Pematangsiantar.

\section{Evaluasi}

\section{a) Komunikasi pada PT Taspen (Persero) Cabang Pematangsiantar}

Dalam pelaksanaannya PT. Taspen (Persero) Cabang Pematangsiantar masih terdapat kekurangan-kekurangan dalam menerapkan konsep komunikator untuk kategori pimpinan 
memahami kebutuhan karyawan. Hal ini dibuktikan dengan jawaban responden yang berada pada ratarata 3,59 dan masih berada di bawah rata-rata total jawaban responden yaitu sebesar 3,78. Untuk mengatasi hal ini sebaiknya pimpinan lebih memperhatikan kebutuhan para karyawannya dengan melakukan berbagai pendekatan dengan para bawahannya.

PT. Taspen (Persero) Cabang Pematangsiantar juga mengalami kendala dalam melaksanakan konsep pesan. Untuk mengatasi hal diatas sebaiknya pimpinan memiliki kemampuan berkomunikasi yang mudah dipahami oleh para bawahannya. Untuk mengatasi kendala dalam melaksanakan konsep saluran sebaiknya pimpinan melakukan pelatihan terhadap bawahannya mengenai hal-hal yang menyangkut media elektronika, karena tidak semua karyawan memiliki kemampuan yang sama dalam pemahaman pemberian tugas melalui media elektronik. Kemudian untuk mengatasi hal-hal diatas sebaiknya dilakukan pendekatan antara pimpinan dan bawahan atau sebaliknya agar karyawan lebih berani dan terbuka dalam mengemukakan opininya saat melakukan rapat.

\section{b) Kinerja pada PT. Taspen (Persero) Cabang Pematangsiantar}

Kinerja merupakan faktor penentu dalam pencapaian tujuan perusahaan. Kinerja dapat diukur dari indikator yang terdiri dari kuantitas dari hasil, kualitas dari hasil, ketepatan waktu dari hasil, kehadiran dan kemampuan bekerja sama. Kinerja keseluruhan pada PT. Taspen (Persero) Cabang Pematangsiantar berdasarkan hasil penelitian cukup tinggi, baik dari segi kuantitas dari hasil, kualitas dari hasil, ketepatan waktu dari hasil, kehadiran dan kemampuan bekerjasama.

Dari segi kualitas dengan kategori mutu pekerjaan yang diselesaikan dibanding karyawan lain dengan nilai 3,62 dan standar kualitas karyawan dibandingkan standar resmi yang ada dengan nilai 3,69. Hal ini dapat dibuktikan dari nilai rata-rata dari pendapat responden yang masih berada di bawah nilai rata-rata total jawaban responden yaitu 3,85 . Untuk itu perusahaan perlu memberikan pelatihan kepada karyawan agar mampu memaksimalkan produktivitas sehingga mutu dari pekerjaan karyawan sesuai dengan ketentuan perusahaan.

Untuk mengatasi kendala dari segi kemampuan bekerja sama pada kategori kemampuan untuk bekerja sama dengan pimpinan, pimpinan perlu mengkomunikasikan tujuan perusahaan dengan para karyawan dan meminta karyawan untuk memberikan feedback. Komunikasi yang dilakukan harus dua arah sehingga pimpinan tahu apa yang dibutuhkan karyawan dan juga sebaliknya.

Karyawan sebagai sumber daya manusia sangat penting mengingat perannya yang sangat vital dalam perusahaan. Kunci untuk memajukan perusahaan berada pada karyawan. Untuk meningkatkan kinerja, salah satu langkah yang dapat dilakukan perusahaan adalah meningkatkan komunikasi karyawan. Semakin baik hubungan komunikasi yang dilakukan maka akan semakin tinggi kinerja yang dihasilkan.

\section{KESIMPULAN DAN SARAN}

\section{Kesimpulan}

a. Dari hasil pengolahan kuesioner tentang komunikasi memiliki nilai rata-rata 3,78 dengan kriteria baik. Akan tetapi masih terdapat kelemahan PT. Taspen (Persero) Cabang Pematangsiantar untuk indikator komunikator, pesan, dan saluran.

b. Dari hasil pengolahan kuesioner tentang kinerja karyawan memiliki nilai rata-rata 3,85 dengan kriteria tinggi. Akan tetapi masih terdapat kelemahan PT. Taspen (Persero) Cabang Pematangsiantar untuk indikator kualitas, ketepatan waktu, dan kemampuan bekerja sama yang masih di bawah nilai rata-rata.

c. Hasil pengujian regresi komunikasi terhadap kinerja karyawan, dapat dilihat dalam persamaan regresi $\hat{\mathrm{Y}}=5,6+0,87 \mathrm{X}$. Hal ini menunjukkan bahwa terdapat pengaruh yang positif antara komunikasi $(\mathrm{X})$ terhadap kinerja $(\mathrm{Y})$ karyawan pada PT. Taspen (Persero) Cabang Pematangsiantar.

d. Melalui analisa koefisien korelasi diketahui bahwa terdapat hubungan yang kuat dan positif antara komunikasi terhadap kinerja sebesar 0,78. Hal ini menunjukkan bahwa semakin baik hubungan komunikasi yang dilakukan maka semakin tinggi pula kinerja yang dihasilkan karyawan pada PT. Taspen (Persero) Cabang Pematangsiantar. Analisa koefisien determinasi menunjukkan tinggi rendahnya kinerja dapat dijelaskan oleh komunikasi sebesar $60,84 \%$, sedangkan $39,16 \%$ dipengaruhi oleh faktorfaktor lain yang tidak dibahas pada penelitian ini.

e. Melalui perhitungan uji $t$ dengan taraf signifikansi $5 \%$ disimpulkan bahwa nilai $t_{\text {hit }}$ $(6,47)>t_{\text {tab }}(2,052)$ sehingga $\mathrm{H}_{0}$ ditolak. Hasil tersebut menunjukkan bahwa komunikasi memiliki pengaruh positif terhadap kinerja karyawan pada PT. Taspen (Persero) Cabang Pematangsiantar.

\section{Saran}

a. Agar penerapan komunikasi berdasarkan indikator komunikator, komunikan, pesan, saluran, dan efek dapat dimiliki karyawan pada PT. Taspen (Persero) Cabang Pematangsiantar, perusahaan perlu meningkatkan komunikator dengan pimpinan melakukan pendekatan kepada para bawahnya sehingga pimpinan mengetahui kebutuhan karyawannya. Pada indikator pesan, hendaknya pimpinan dan bawahan mampu berkomunikasi dengan baik dan jelas sehingga dapat menyampaikan maksud dan tujuan dengan tepat dan jelas. Kemudian pada indikator saluran, sebaiknya pimpinan mengadakan pelatihan media elektronik kepada para karyawannya agar semua mampu menerima tugas yang diberikan 
pimpinan dengan bekal pelatihan yang dilakukan. Selain itu, karyawan juga harus dituntut berani dalam menyampaikan opini saat sedang melakukan rapat.

b. Agar kinerja dapat lebih optimal pada PT. Taspen (Persero) Cabang Pematangsiantar, perusahaan perlu memberikan pekerjaan dengan kuantitas yang meningkat dari waktu ke waktu sehingga kualitas yang dihasilkan semakin baik, serta memberikan pekerjaan ekstra. Hal tersebut guna melatih karyawan agar tidak kewalahan dalam menyelesaikan kuantitas kerja yang sewaktu-waktu bisa bertambah. Dalam meningkatkan kualitas, perusahaan perlu memberikan pelatihan kepada karyawan agar mampu memaksimalkan produktivitas sehingga mutu dari pekerjaan karyawan sesuai dengan ketentuan perusahaan. Dalam ketepatan waktu, perusahaan meningkatkan pengembangan karyawan secara berkala. Pengembangan karyawan seperti training ataupun seminar, agar karyawan mampu dan tepat waktu dalam melaksanakan pekerjaan. Kemudian untuk kemampuan bekerjasama, pimpinan perlu mengkomunikasikan tujuan perusahaan dengan para karyawan dan meminta karyawan untuk memberikan feedback. Komunikasi yang dilakukan harus dua arah sehingga pimpinan tahu apa yang dibutuhkan karyawan dan juga sebaliknya.

c. Sehubungan dengan keterbatasan-keterbatasan yang ada pada penulis, penelitian ini masih terdapat kelemahan-kelemahan dan belum dapat mengungkap seluruh variabel yang dapat mempengaruhi kinerja karyawan pada PT.
Taspen (Persero) Cabang Pematangsiantar. Sebagai bahan masukan untuk penelitian selanjutnya, perlu memperbanyak variabel penelitian, seperti motivasi, kepemimpinan, lingkungan kerja, perencanaan karir, dan pendelegasian wewenang.

\section{3) DAFTAR PUSTAKA}

Daft, Richard L, 2007, Management-Manajemen, Edisi keenam, Edisi 1, Jakarta : Salemba Empat.

Dessler, Gary, 2006, Manajemen Sumber Daya Manusia, Edisi Kesepuluh, Jilid I, Jakarta : PT. Indeks.

Dewi, Sutrisna, 2007, Komunikasi Bisnis, Yogyakarta : Penerbit Andi.

Halim, Fitria, 2012, Pengaruh Komunikasi terhadap Kinerja Karyawan, Pematangsiantar : STIE Sultan Agung. Skripsi.

Luthans, Fred, 2006, Komunikasi Bisnis, Edisi Sepuluh, Yogyakarta : Penerbit Andi.

Mathis, Robert L. dan John H. Jackson, 2006, Human Resources Management (Manajemen Sumber Daya Manusia), Edisi 10, Jakarta : Salemba.

Mondy,R. Wayne, 2008, Manajemen Sumber Daya Manusia, Jakarta : Penerbit Erlangga.

Purwanto, Djoko, 2006, Komunikasi Bisnis, Edisi Ketiga, Jakarta : Penerbit Erlangga.

Sutrisno, Edy, 2010, Budaya Organisasi, Cetakan Pertama, Edisi Pertama, Jakarta: Prenada Media Group

Wibowo, 2007, Manajemen Kinerja, Jakarta : Rajawali Pers. 